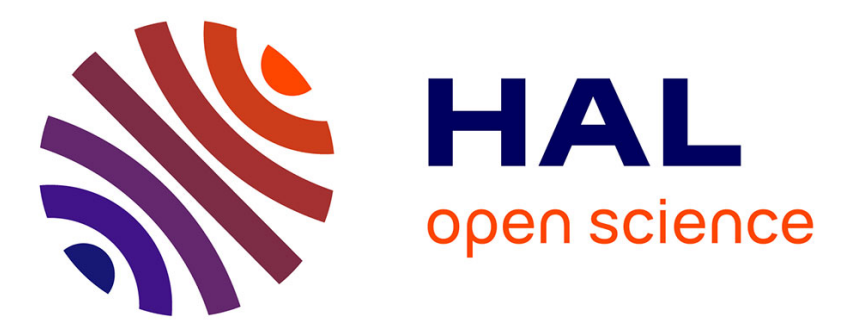

\title{
Zika virus infection in French Polynesia
}

Jean-Marie Jouannic, Stephanie Friszer, Isabelle Leparc-Goffart, Catherine Garel, Dominique Eyrolle-Guignot

\section{To cite this version:}

Jean-Marie Jouannic, Stephanie Friszer, Isabelle Leparc-Goffart, Catherine Garel, Dominique EyrolleGuignot. Zika virus infection in French Polynesia. The Lancet, 2016, 387 (10023), pp.1051-1052. 10.1016/S0140-6736(16)00625-5 . hal-01291986

\section{HAL Id: hal-01291986 https://hal.sorbonne-universite.fr/hal-01291986}

Submitted on 22 Mar 2016

HAL is a multi-disciplinary open access archive for the deposit and dissemination of scientific research documents, whether they are published or not. The documents may come from teaching and research institutions in France or abroad, or from public or private research centers.
L'archive ouverte pluridisciplinaire HAL, est destinée au dépôt et à la diffusion de documents scientifiques de niveau recherche, publiés ou non, émanant des établissements d'enseignement et de recherche français ou étrangers, des laboratoires publics ou privés. 


\section{French Polynesian experience with maternofoetal Zika virus}

\section{infection}

Jouannic $\mathrm{JM}^{1}, \mathrm{MD}$, PhD, Friszer $\mathrm{S}, \mathrm{MD}^{1}$, Leparc-Goffart $\mathrm{I}^{2}, \mathrm{MD}, \mathrm{PhD}$, Garel $\mathrm{C}^{3}, \mathrm{MD}$, Eyrolle-Guignot D, $\mathrm{MD}^{4}$

${ }^{1}$ Service de Médecine Foetale, Hôpital Armand Trousseau, APHP, Paris 6, 26 Avenue du Docteur A. Netter, 75012 Paris, France

${ }^{2}$ Centre National de Référence des arbovirus, Institut de Recherche Biomédicale des Armées, Service de Biologie, Hôpital d'Instruction des Armées Laveran, 34 Boulevard Laveran, 13013 Marseille, France

${ }^{3}$ Service de Radiologie Pédiatrique, Hôpital Armand Trousseau, APHP, Paris 6, 26 Avenue du Docteur A. Netter, 75012 Paris, France

${ }^{4}$ Service de Gynécologie-Obstétrique, CHT Mamao, 98713 Papeete

Corresponding author : $\operatorname{Pr}$ JM Jouannic, Service de Médecine Foetale, Hôpital Armand Trousseau, APHP, Paris 6, 26 Avenue du Docteur A. Netter, 75012 Paris, France

Tel: $+33-14473-5228$ Fax: +33-14473-5222

Email: jean-marie.jouannic@aphp.fr

Conflict of interest: none

Contribution:

JMJ, SF, CG, DEG were in charge of the patients

JMJ, SF wrote the manuscript

ILG performed the PCR on amniotic fluids

Key words: zika virus, prenatal diagnosis, fetal, cerebral anomalies, ultrasound Word count: 499 
The World Health Organization issued an alert on February $2^{\text {nd1,2 }}$ on the potential fetal consequences of the Zika virus outbreak after the Brazilian authorities reported an abnormal increase in the number of cases of neonates born with microcephaly ${ }^{3}$. Although no causal link could be clearly established, circumstantial evidence was considered worrisome enough for several countries to discourage pregnant women to travel to Central and South America ${ }^{4}$.

French Polynesia was affected by an epidemic of Zika between September 2013 and March 2014 with an estimated 28,000 patients affected, representing around $11.5 \%$ of the Polynesian population ${ }^{5}$. During 2014, local clinicians were struck by an unusual rate of cerebral congenital anomalies. Within this territory, approximately 4,000 births are recorded each year. All cases of suspected fetal abnormalities detected during routine prenatal ultrasound examinations are referred to Papeete Hospital. When the referral examination confirms the presence of fetal cerebral anomalies, neuroimaging examinations (ultrasound and/or MRI) are transmitted to the reference center of Trousseau Hospital in Paris for evaluation by experts in fetal neuroimagery. In 2014, 13 cases of fetal cerebral anomalies were diagnosed instead of four and three in the two previous years. In addition, five neonates are currently under investigation for neurological signs of brainstem dysfunction. As part of the prenatal evaluation of the 13 cases of fetal cerebral anomalies, amniocentesis was offered to all women for fetal karyotype and CMV detection by PCR, and performed in 10 cases. Following the Brazilian alert on possible fetal cerebral damage secondary to maternal Zika infection, we retrospectively tested 6 available stored amniotic fluid samples using PCR. Among those, four were found positive for Zika virus. The fetal brain anomalies depicted in 
these cases are presented in the table. Microcephaly (Head Circumference $<3$ th centile) was constant but was observed after 28 weeks of gestation in two cases. Nevertheless, in case 1, ventriculomegaly was present at the second trimester routine scan. In case 3 , the first scan was performed at $29^{+2}$ weeks of gestation. Severe abnormalities of midline structures and the cerebellum as well as abnormal gyration were observed, which may reflect an early embryologic hit of the developing brain. Thus, a common maternal viral history during the $1^{\text {st }}$ trimester of pregnancy was reported in three out of four cases.

Only two observations of severe fetal brain damage were recently reported in the Brazilian population ${ }^{6}$. Our population-based experience should raise awareness regarding the fetal risks of Zika materno-fetal infection. It is likely that the true incidence of severe forms of fetal infection has been underestimated in our Polynesian population as we were unable to test all cases retrospectively.

Considering the potential severity of the fetal lesions, congenital Zika virus infection seems available to ultrasound imaging. Fetal neurosonography should be considered from the $2^{\text {nd }}$ trimester in cases of maternal proven Zika virus infection in order to detect subtle cerebral anomalies that may precede the onset of microcephaly. Since we currently do not know the natural history of Zika virus fetal congenital infection, repeated ultrasound examinations should be considered.

\section{References}


1. Torjesen I. Zika virus outbreaks prompt warnings to pregnant women. BMJ. 2016;352:i500.

2. Zika virus: a new global threat for 2016. Lancet Lond Engl. 2016 Jan 9;387(10014):96.

3. Schuler-Faccini L, Ribeiro EM, Feitosa IML, Horovitz DDG, Cavalcanti DP, Pessoa A, et al. Possible Association Between Zika Virus Infection and Microcephaly - Brazil, 2015. MMWR Morb Mortal Wkly Rep. 2016;65(3):59-62.

4. Petersen EE, Staples JE, Meaney-Delman D, Fischer M, Ellington SR, Callaghan WM, et al. Interim Guidelines for Pregnant Women During a Zika Virus Outbreak - United States, 2016. MMWR Morb Mortal Wkly Rep. 2016;65(2):30-3.

5. European Center for Disease Prevention and Control. Rapid risk assessment: Zika virus infection outbreak, French Polynesia: EDCD; 2014 [updated 2014 Feb 14].

6. Oliveira Melo AS, Malinger G, Ximenes R, Szejnfeld PO, Alves Sampaio S, Bispo de Filippis AM. Zika virus intrauterine infection causes fetal brain abnormality and microcephaly: tip of the iceberg? Ultrasound Obstet Gynecol Off J Int Soc Ultrasound Obstet Gynecol. 2016 Jan;47(1):6-7. 